\title{
THE COACH-ATHLETE RELATIONSHIP OF YOUNG TALENTED ATHLETES FROM BOSNIA AND HERZEGOVINA
}

\section{RELACIÓN ENTRENADOR- DEPORTISTA DE CATEGORÍAS DE EDAD MÁS JÓVEN DE BOSNIA Y HERZEGOVINA}

\author{
Siniša Vukadinović ${ }^{1}$, Nenad Rađević ${ }^{2}$ \\ ${ }^{1}$ Faculty of Physical Education and Sport, University of Banja Luka, Bosnia and Herzegovina \\ ${ }^{2}$ Ministry of Family, Youth and Sports; Government of Republika Srpska, Banja Luka, Bosnia and Herzegovina
}

\begin{abstract}
This study is focused on getting feedback on positive and negative aspects of coach-athletes relationship and defining the quality of this relationship, as well as their implications to both coaches' and athletes' work. The multivariate analysis of variance shows that the interaction between athletes' gender and type of sport is significant for all three subtests (social support, depth and conflict) of the Quality Relationship Inventory questionnaire. Significant differences are noticed with young athletes receiving social support by their coaches, while individual athletes have shown a higher level of social support than their peers from team sports. The results of this study suggest that male individual sports ahletes shows tenacious connection (depth) with their coaches, while the situation for the team sports is reversed. Also, female athletes have shown a higher level of conflict with their coaches in individual sports, whilst the level of conflict with male athletes is more common in team sports. Coach's support is of a high importance due to a significantly weakened relationship between athletes and parents in the age of adolescence. The coach is a person who has to play more active role in overall young athletes' personality development and thus the qualification of the staff working with younger age categories has to be at the highest level of their competences.
\end{abstract}

Key words: SOCIAL SUPPORT / ADOLESCENCE / QUALITY RELATIONSHIP INVENTORY / COMPETENCES / DEVELOPMENT

\begin{abstract}
EXTRACTO
El presente estudio está dirigido hacia obtener las informaciones feedback sobre los aspectos positivos y negativos de la relación entre entrenadores y deportistas, definir la calidad de esas relaciones, así como también sobre sus implicaciones en el trabajo de entrenadores, pero también de los deportistas. El análisis de variancia en el diseño multivariante demuestra que la interacción entre el sexo del deportista y el tipo de deporte es significante para todas las tres subpruebas (apoyo social, profundidad y conflicto) del cuestionario Quality Relationship Inventory. Se notan importantes diferencias en el apoyo social que los jóvenes deportistas reciben de sus entrenadores y los deportistas individuales demostraron un mayor nivel de apoyo social que sus coetáneos de los deportes de equipo. Los resultados de esta investigación indican que los deportistas de los deportes individuales realizan un vínculo más fuerte con su entrenador que las deportistas, mientras que en los deportes de equipo la situación es al revés. Las deportistas mostraron, también, un poco mayor nivel de conflictos con sus entrenadores en los deportes individuales, mientras que en los deportes de equipo los deportistas varones están más inclinados hacia conflictos. El apoyo de entrenador tiene de verdad un gran peso porque la relación entre el deportista y sus padres en el período de adolescencia se debilita considerablemente. El entrenador es aquel que tiene que tener un papel más activo en el desarrollo completo de la personalidad de los jóvenes deportistas y con eso la calidad y el profesionalismo de los cuadros que trabajan con las categorías de edades más jóvenes tiene que ser en el máximo nivel posible.
\end{abstract}

Palabras claves: APOYO SOCIAL / ADOLESCENCIA / QUALITY RELATIONSHIP INVENTORY / COMPETENCIA / DESARROLLO 
Vukadinović, S., Rađević N., The Coach-Athlete Relationship.., PHYSICAL CULTURE 2019; 73 (2): 230-237

\section{INTRODUCTION}

Sport plays an essential role in the overall development of personality and through organized sports activities young people have the opportunity of physical, social, psychological and educational development. The environment and climate in sports are factors that create positive conditions for the proper development of young athletes. Therefore, as a very important factor in sports, especially with young athletes, the relationship between coaches and athletes is observed, too.

Horn (2008) and Krevsel (2001) state that the coach is a primary factor in the overall development of young athletes. Their interdependence manifests itself through the need of athletes to adopt the skills, competences and experience from their coaches, i.e. the need of coaches to transfer their acquired competences and knowledge into achievements and successes of athletes (Antonini Philippe \& Seiler, 2006). Essential factors of team and individual success in sports are devotion and trust in this relationship (Nikbin, Hyun, Iranmanesh, \& Foroughi, 2014). Erickson and Côté (2016) point to importance of maintaining a good relationship between coaches and athletes at all levels. Jowett (2017) even states that the relationship between a coach and athlete is the essence of coach's job and that relationship defines trainers' working efficiency. A coach should develop and improve his/her pedagogical competences continuously in order to make a positive influence on development and professional success of an athlete (Kuljić, Čokorilo, \& Grk, 2010).

In addition to having an influence on sport development of young athletes, a coach has a very important role in shaping psychosocial experiences of children and youth within sports (Moran \& Weiss, 2006). Rutten et al. (2008) emphasize the role that organized sport has in the socialization of young athletes. Sheridan, Coffee and Lavallee (2014) point out that the combined effect of parental, coach and peer's support is invaluable in shaping the positive and negative experiences of young athletes. However, it has been concluded that the coach is the most important social support factor in sports with young athletes. The results show that coaches who keep good relationships with athletes reduce the possibility of antisocial behaviour (Rutten et al., 2007), as well as increase personal satisfaction and happiness of athletes they are coaching (Davis \& Jowett, 2014; Jowett et al., 2017; Lafrenière, Jowett, Vallerand, \& Carbonneau, 2011; Lafrenière, Jowett, Vallerand, Donahue, \& Lorimer, 2008). On the other hand, an important factor that determines the quality of coach-athlete relationship is the character of the athlete (Aşçi, Kelecek, \& Altintaş, 2015). Certainly, the essential assumption is that the behaviour of a coach has an influence on motivation of athletes to the great extent (Mageau \& Vallerand, 2003; Olympiou, Jowett, \& Duda, 2008). The results of a study made on a model of Greek students by Chartoff (2017) show that getting involved in various social groups, such as sports teams, might be of a crucial importance in students' fighting against mental illness.

In addition, one of literature focuses was parental influence on coach-athlete relationship quality (Jowett \& Timson-Katchis, 2005), as well as relationship between parents and coaches in youth sports (Preston \& Fraser-Thomas, 2016), while Jowett and Cramer (2010) conclude that coach-athlete relationship quality has much stronger influence on physical selfconfidence than their relationship with parents. Jowett and Chaundy (2004) were researching the influence of coach-athlete relationship on social cohesion, while Isoard-Gautheur, Trouilloud, Gustafsson and GuilletDescas (2016) tried to find the connection between coach-athlete relationship quality and the too early burn out of young athletes. The relationship between leadership and coach-athlete relationship quality was also researched (Enoksen et al., 2014; Vella, Oades, \& Crowe, 2013). Nicholls and Perry (2016) considered the influence of coach-athlete relationship on stressfacing phenomena and they emphasize that the quality of this relationship is of a particular importance for coaches and of a less importance for an athlete.

Therefore, the coach plays a particularly important role in professional and personal development of athletes, especially because athletes spend most of their time with their coach, which is sometimes much more time than they spend with their parents. Consequently, the main aim of this research is to define the quality of the interpersonal relationship between coaches and athletes by identifying the attitudes of young athletes towards the work and behaviour of their coaches. This research is focused on getting feedback on the positive and negative aspects of this relationship and their implications to both coaches' and athletes' work. 


\section{METHODS}

The sample of examinees involved talented young athletes $(N=228)$ from Bosnia and Herzegovina who participated in "Summer school of sport" in Trebinje city in the summer 2017. The average age of the examinees was $14,69 \pm 0,95$ years. The structure of samples covered 12 sport disciplines, $51,3 \%(n=$ 117) of which were athletes from individual sports and $48,7 \%(n=111)$ of which were athletes from team sports. Gender structure of samples was quite balanced, which means that $46,9 \%(n=107)$ of observed samples were male examinees and $53,1 \%(n=121)$ were female examinees.

The examinees answered Quality Relationship Inventory (QRI) which represents the examination instrument developed by Pierce, Sarason, Sarason, Solky-Butzel and Nagle (1997). QRI is an instrument for examination of different interpersonal and social relationships which has been used quite a lot, but which was used in sports for the first time to explain coachathlete relationship quality (Jowett, 2009). Original QRI used by Pierce et al. (1997) was composed of 25 items, but in this survey we will use the reduced questionnaire developed by Jowett (2009) which is composed of 18 items that measure two positive (social support and depth) and one negative aspect (conflict) of coach-athlete relationship. Every dimension of this relationship was composed of six variables and examinees gave their answers on the scale from 1 (not at all) to 4 (very much). Internal consistency was satisfactory for all three dimensions: Social support ( $\alpha$ $=.77)$, Depth $(\alpha=.71)$ and Conflict $(\alpha=.80)$.

The examinees were familiar with the goal of the research before completing the survey which was optional. The only criterion for completing this survey was that the athlete has been in cooperation with his/her coach for minimum six months. Then, the collected data were statistically processed with IBM SPSS Statistics 21.0. Descriptive statistics was used to show means and standard deviations for all three dimensions of the QRI questionnaire as well as the correlative matrix of these three dimensions. Finally, multivariate analysis of variance (MANOVA) was used to determine potential disagreement in coach-athlete relationship quality assessment.

\section{RESULTS}

Descriptive statistics of QRI scale shows menas and standard deviations in two positive aspects (social support and depth) and one negative aspect (conflict) of coach-athlete relationship (Table 1 and 2). Also, the high correlation between all three subtests of QRI scale was noticeable (Table 1).

Table1. Descriptive statistics among three subtests of QRI scale

\begin{tabular}{lccccc}
\hline Variables & M & SD & Support & Depht & Conflict \\
\hline Support & 3.12 & .54 & - & & - \\
Depht & 3.24 & .47 & $.60^{* *}$ & $-.23^{* *}$ & - \\
Conflict & 1.77 & .61 & & $-.22^{* *}$ &
\end{tabular}

Table 2. Descriptive statistics of observed sample $(\mathrm{N}=228)$

\begin{tabular}{|c|c|c|c|c|c|c|c|c|}
\hline \multirow{3}{*}{ Variables } & \multicolumn{4}{|c|}{ Gender } & \multicolumn{4}{|c|}{ Sport } \\
\hline & \multicolumn{2}{|c|}{ Male } & \multicolumn{2}{|c|}{ Female } & \multicolumn{2}{|c|}{ Individual } & \multicolumn{2}{|c|}{ Team } \\
\hline & $\mathbf{M}$ & SD & $\mathbf{M}$ & SD & $\mathbf{M}$ & SD & $\mathbf{M}$ & SD \\
\hline Support & 3.09 & .57 & 3.15 & .52 & 3.25 & .49 & 2.99 & .56 \\
\hline Depht & 3.22 & .50 & 3.28 & .44 & 3.28 & .49 & 3.21 & .45 \\
\hline Conflict & 1.85 & .53 & 1.72 & .67 & 1.85 & .66 & 1.71 & .55 \\
\hline
\end{tabular}


We wanted to know whether male and female examinees, i.e. individual sports athletes and team sports athletes give equally homogeneous answers or there are some differences. Multivariate analysis of variance indicate that there is a statistically significant interaction between gender and the type of sport in combination of dependent variables (social support, depth and conflict), $\mathrm{F}_{(3,222)}=5.10, p<.01$; Wilks' $\Lambda=$ .93.

On the one hand the type of sport significantly influences the level of social support received from a personal coach, $\mathrm{F}_{(1,228)}=20.06, p<.01$, while gender doesn't have more significant influence in the same view, $\mathrm{F}_{(1,228)}=3.69, p>.05$, and on the other hand the interaction between gender and type of sport significantly influences on social support in the coach-athlete relationship, $\mathrm{F}_{(1,228)}=14.01, p<.01$.

It is noticeable that individual sports athletes have remarkably higher level of social support in relation to team sports athletes, while male individual sports athletes said they have much higher level of social support than those ones from team sports. Moreover, it is noticeable that male individual sports athletes said they have higher level of social support, which is the case with female team sports athletes as well. (Figure 1).

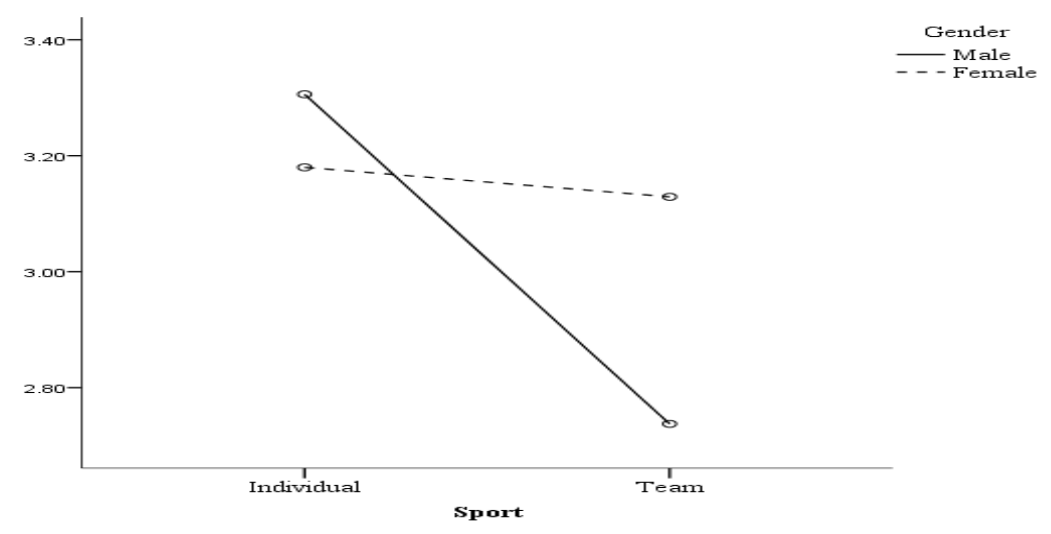

Figure 1. The influence of gender and type of sport on social support in the coach-athlete relationship

The depth of coach-athlete relationship doesn't defer significantly among individual sports athletes, i.e. team sports athletes, $\mathrm{F}_{(1,228)}=2.73, p>.05$, neither in terms of gender of athlete, $\mathrm{F}_{(1,228)}=1.89, p>.05$, while the interaction between gender and type of sport statistically significant difference is noticeable
, $\mathrm{F}_{(1,228)}=5.46, p<.05$. Individual sport increases the relationship depth between a coach and an athlete with male examinees, whilst it decreases the relationship depth between a coach and an athlete with female examinees and vice versa for team sports (Figure 2).

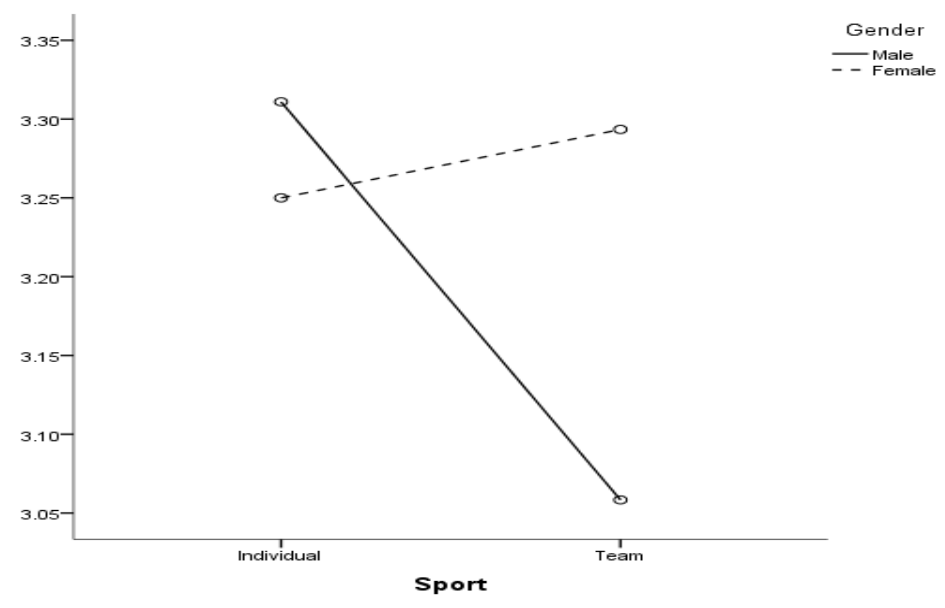

Figure 2. The influence of gender and type of sport on depth in the coach-athlete relationship 
On the other side, there was no significant statistical difference found to the conflict concerning coach-athlete relationship, nor to both gender of the athlete, $\mathrm{F}_{(1,228)}=1.98, p>.05$, and type of sport done by an athlete, $\mathrm{F}_{(1,228)}=1.63, p>.05$, while in interaction between gender and sport type statistically significant difference was found $\mathrm{F}_{(1,228)}=4.24, p<.05$. Individual sport increases the level of conflict with female athletes, whilst the level of conflict with male athletes is more common in team sports (Figure 3).

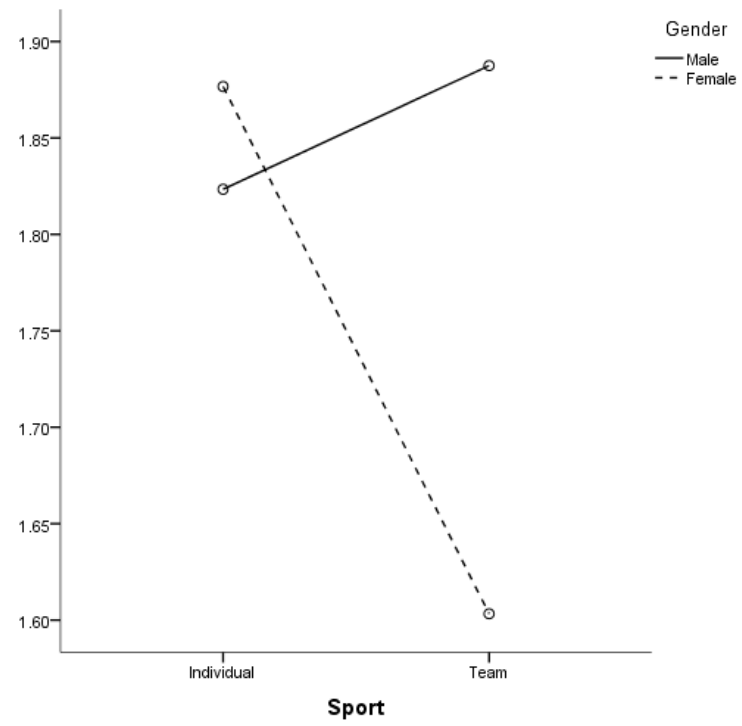

Figure 3. The influence of gender and type of sport on conflict in the coach-athlete relationship.

\section{DISCUSSION}

This survey has been conducted to define the quality of interpersonal relationship between a coach and athletes by identifying young athletes' attitude towards the work and behaviour of their coaches. We have come to major conclusions which can have direct influence on both coach and athletes' work.

Three subtests (social support, depth and conflict), each one for itself, elapse equally homogeneously with both male and female examinees. Therefore, it can be concluded that a gender of an athlete does not play a significant role in the interpersonal relationships between young athletes from Bosnia and Herzegovina and their coaches. Slightly higher level of two positive aspects of this relationship has been shown by female athletes, while male athletes are expectantly more well-disposed toward conflict than females. More significant differences are noticeable between individual sport athletes and team sport athletes, while interaction between athletes' gender and type of sport is significant for all three subtests of QRI questionnaire. Individual athletes have shown higher level in all three aspects of coach-athlete relationship. Still, from the social support aspect of this relationship, individual sports athletes have shown significantly higher level by comparison with their colleagues from team sports. This could lead us to a conclusion that individual sports coaches are more dedicated and more passionate in their work, which can be a good indicator of quality of coachathlete relationship (Lafrenière, Jowett, Vallerand, \& Carbonneau, 2011). Enoksen and partners (2014) also specify that team sports coaches behave much more autocratically than their colleagues from individual sports. In addition, they say that more experienced coaches pay more attention to social support than those with less experience. In this survey the aspects of coach-athlete relationship with regard to coach' experience or coaching style were not observed, but the results of the survey can be related to this cognition because it is clear that coach's behaviour style and work directly imply to social support and social cohesion. The coaching style and the relationship with athletes can have essential long term implications to children's motivation for getting involved in some type of sport, as well as to possible fluctuations of young athletes. 
Successfully conflict resolving between the team and a coach should definitely be important experience for young athletes considering that it would help in reducing peer violence. Moreover, Jowett and Cramer (2010) emphasize that present conflict in this relationship can lead to young athletes' physical skills decrease.

Sheridan, Coffee and Lavallee (2014) point that the coach is the most important factor regarding social support with young athletes and his role, besides parents and peers' support, should be main initiator and motivator in any type of sport. As a matter of fact, a coach should have an important role in overall development and progress of young athletes, which can certainly lead to better sport results and achievement of key goals of a team (Nicholls, Earle, Earle, \& Madigan, 2017). Therefore, it can be concluded that quality of coach-athlete relationship affects more factors important for young athletes and coaches, such as antisocial behavior of young athletes (Rutten et al., 2007; Rutten et al., 2008), too early burn out of athletes (Isoard-Gautheur, Trouilloud, Gustafsson, \& Guillet-Descas, 2016), efficiency in coaching (Jowett, 2017) and other relevant aspects.

\section{CONCLUSION}

Doing any sport sets high criterion of success for both coaches and athletes which is the reason why

\section{REFERENCES}

1. Antonini Phillipe, R., \& Seiler, R. (2006). Closeness, co-orentation and complementarity in coach-athlete relationship: What male swimmers say about their male coaches. Psychology of Sport and Exercise, 7(2), 159-171.

2. Aşçi, F. H., Kelecek, S., \& Altintaş, A. (2015). The Role of Personality Characteristics of Athletes in Coach-Athlete Relationships. Perceptual and Motor Skills, 121(2), 399-411.

3. Chartoff, B. (2017). Does Social Support Diminish Depression in Students? Evidence from Athletes and Greek Life. EKU Libraries Research Award for Undergraduates, 9. Retrieved from the coach-athlete relationship should be crucial in achieving excellent results in sport. This relationship is particularly important in the age of adolescence when the parents-athlete relationship is getting weaker and interpersonal relations and knowledge gained in that period of life of a young athlete are accumulating for a lifetime, whether they are positive or negative. In the age of adolescence athletes usually spend much more time with coaches than with their parents, so coach's role in this period of young athlete's life is crucial and therefore it is very important that the coach is highly competent, educated and skilled in his job with young ages.

The starting point in this relationship must certainly be communication, which is of a vital importance for psychosocial acting of both actors in this relationship and thus for achievement in sport. Aşçi et al. (2015) also point to the importance of athlete's character as very important potential predictor of quality of relationship between an athlete and a coach. Based on this fact, further steps in the research could possibly develop towards testing the influence of young athlete's character on the coachathlete relationship. On the other hand, considering that the quality of coach-athlete relationship may impact on sport achievements to the great extent, the next survey should be focused on the influence of the quality coach-athlete relationship on self-confidence and anxiety phenomenon of young athletes and thereby on their sport achievements.

http://encompass.eku.edu/cgi/viewcontent. cgi ?article $=1040 \&$ context $=$ ugra .

4. Davis, L., \& Jowett, S. (2014). Coach-athlete attachment and the quality of the coach-athlete relationship: implications for athlete's well-being. Journal of Sports Sciences, 32(15), 1454-1464.

5. Enoksen, E., Fahlström, P. G., Johansen, B. T., Hageskog, C. A., Christensen, J. B., \& Høigaard, R. (2014). Perceptions of leadership behavior and the relationships to athletes among Scandinavian coaches. Scandinavian Sport Studies Forum, 5, 131-147. 
6. Erickson, K., \& Côté, J. (2016). A season-long examination of the intervention tone of coachathlete interactions and athlete development in youth sport. Psychology of Sport and Exercise, 22, 264-272.

7. Horn, T. (2008). Coaching effectiveness in the sport domain. In T. Horn (Ed.) Advances in sport psychology (3rd ed., pp. 239-267). Champaign, Il: Human Kinetics.

8. Isoard-Gautheur, S., Trouilloud, D., Gustafsson, H., \& Guillet-Descas, E. (2016). Associations between the perceived quality of the coach-athlete relationship and athlete burnout: An examination of the mediating role of achievement goals. Psychology of Sport and Exercise, 22, 210-217.

9. Jowett, S., Adie, J. W., Bartholomew, K. J., Yang, S. X., Gustafsson, H., \& Lopez-Jiménez, A. (2017). Motivational processes in the coach-athlete relationship: A multi-cultural self-determination approach. Psychology of Sport and Exercise, 32, 143-152.

10. Jowett, S. (2017). Coaching effectiveness: the coach-athlete relationship at its heart. Current Opinion in Psychology, 16, 154-158.

11. Jowett, S., \& Chaundy, V. (2004). An Investigation Into the Impact of CoachLeadership and CoachAthlete Relationship on Group Cohesion. Group Dynamics: Theory, Research, and Practice, 8(4), 302-311.

12. Jowett, S., \& Cramer, D. (2010). The predicition of young athletes' physical self from perceptions of relationships with parents and coaches. Psychology of Sport and Exercise, 11, 140-147.

13. Jowett, S., \& Timson-Katchis, M. (2005). Social Networks in Sport: Parental Influence on the Coach-Athlete Relationship. The Sport Psychologist, 19, 267-287.

14. Jowett, S. (2009). Validating Coach-Athlete Relationship Measures with the Nomological Network. Measurement in Physical Education and Exercise Science, 13, 34-51.

15. Krevsel, V. (2001). Poklic športnega trenerja [The profession of a coach. In Slovenian]. Ljubljana: Univerza v Ljubljani, Fakulteta za šport, Inštitut za šport.

16. Kuljić, R., Čokorilo, R., \& Grk, M. (2010). Socioprofesionalni status trenera i doživljaj sopstvene pedagoške kompetencije [Socio-professional sta- tus of coaches and subjective experience of pedagogical competence]. Proceedings, 2, 65-75.

17. Lafrenière, M. A. K., Jowett, S., Vallerand, R. J., \& Carbonneau, N. (2011). Passion for coaching and the quality of the coach-athlete relationship: The mediating role of coaching behaviors. Psychology of Sport and Exercise, 12, 144-152.

18. Lafrenière, M. A. K., Jowett, S., Vallerand, R. J., Donahue, E. G., Lorimer, R. (2008). Passion in Sport: On the Quality of the Coach-Athlete Relationship. Journal of Sport and Exercise Psychology, 30, 541-560.

19. Mageau, G. A., \& Vallerand, R. J. (2003). The coach-athlete relationship: a motivational model. Journal of Sports Sciences, 21(11), 883-904.

20. Moran, M. M., \& Weiss, M. R. (2006). Peer leadership in sport: links with friendship, peer acceptance, psychological characteristics, and athletic ability. Journal of Applied Sport Psychology, 18, 97-113.

21. Nicholls, A. R., \& Perry, J. L. (2016). Perceptions of Coach-Athlete Relationship Are More Important to Coaches than Athletes in Predicting Dyadic Coping and Stress Appraisals: An ActorPartner Independence Mediation Model. Frontiers in Psychology, 7, 1-12.

22. Nicholls, A. R., Earle, K., Earle, F., \& Madigan, D. J. (2017). Perceptions of the Coach-Athlete Relationship Predict the Attainment of Mastery Achievement Goals Six Months Later: A TwoWave Longitudinal Study among F. A. Premier League Academy Soccer Players. Frontiers in Psychology, 8, 1-8.

23. Nikbin, D., Hyun, S. S., Iranmanesh, M., \& Foroughi, B. (2014). Effects of Perceived Justice for Coaches on Athletes' Trust, Commitment, and Perceived Performance: A Study of Futsal and Volleyball Players. International Journal of Sports Science \& Coaching, 9(4), 561-577.

24. Olympiou, A., Jowett, S., \& Duda, J. L. (2008). The Psychological Interface Between the Coach-Created Motivational Climate and the Coach-Athlete Relationship in Team Sports. The Sport Psychologist, 22, 423-438.

25. Pierce, G. R., Sarason, I. G., Sarason, B. R., SolkyButzel, J. A., \& Nagle, L. C. (1997). Assessing the quality of personal relationships. Journal of Social and Personal Relationships, 14, 339-356. 
26. Preston, C., \& Fraser-Thomas, J. (2016). The parent-coach relationship within elite youth sport: Contentious or cooperative. Journal of Exercise, Movement, and Sport, 48(1), 125.

27. Rutten, E. A., Stams, G. J. J. M., Biesta, G. J. J., Schuengel, C., Dirks, E., \& Hoeksma, J. B. (2007). The Contribution of Organized Youth Sport to Antisocial and Prosocial Behavior in Adolescent Athletes. J Youth Adolescence, 36, 255-264.

28. Rutten, E. A., Deković, M., Stams, G. J. J. M., Schuengel, C., Hoeksma, J. B., \& Biesta, G. J. J. (2008). On-and off-field antisocial and prosocial behavior in adolescent soccer players: A multilevel study. Journal of Adolescence, 31(3), 371-387.
29. Sheridan, D., Coffee, P., \& Lavallee, D. (2014). A systematic review of social support in youth sport. International Review of Sport and Exercise Psychology, 7(1), 198-228.

30. Vella, S. A., Oades, L. G., \& Crowe, T. P. (2013). The relationship between coach leadership, the coach-athlete relationship, team success, and the positive developmental experiences of adolescent soccer players. Physical Education and Sport Pedagogy, 18(5), 549-561.

Submitted: 26.02.2019.

Accepted: 25.03. 2019.

Published Online First: 26.07.2019. 


\title{
ОДНОС ТРЕНЕР-СПОРТИСТА МЛАЂИХ УЗРАСНИХ КАТЕГОРИЈА ИЗ БОСНЕ И ХЕРЦЕГОВИНЕ
}

\author{
Синиша Вукадиновић ${ }^{1}$, Ненад Рађевић ${ }^{2}$ \\ ${ }^{1}$ Факултет физичког васпитања и спорта, Универзитет у Бања Луци, Босна и Херцеговина \\ ${ }^{2}$ Министарство породице, омладине и спорта, Влада Републике Српске, Бања Лука, Босна и Херцеговина
}

\begin{abstract}
Сажетак
Ова студија је усмјерена на добијање повратне информације о позитивним и негативним аспектима односа између тренера и спортиста, дефинисање квалитета ових односа као и њиховим импликацијама на рад тренера, али и спортиста. Анализа варијансе у мултиваријантном дизајну показује да је интеракција пола спортисте и врсте спорта значајна за сва три субтеста (социјална подршка, дубина и конфликт) Quality Relationship Inventory упитника. Значајне разлике су примјетне у социјалној подршци коју млади спортисти добијају од својих тренера, а индивидуални спортисти су исказали виши ниво социјалне подршке од својих вршњака из екипних спортова. Резултати овог истраживања указују да спортисти из индивидуалних спортова остварују јачу везу са својим тренерима од спортисткиња, док је за екипне спортове ситуација обрнута. Такође, спортисткиње су исказале нешто виши ниво конфликта са својим тренерима у индивидуалним спортовима, док су у екипним спортовима склонији конфликту спортисти мушког пола. Подршка тренера заиста има велику тежину зато што однос спортисте и родитеља у периоду адолесценције значајно слаби. Тренер је тај који мора имати активнију улогу у свеукупном развоју личности младих спортиста и тиме квалитет и стручност кадра који ради са млађим узрасним категоријама мора бити на највишем могућем нивоу.
\end{abstract}

Кључне ријечи: СОЦИЈАЛНА ПОДРШКА / АДОЛЕСЦЕНЦИЈА / QUALITY RELATIONSHIP INVENTORY / КOMПЕTЕНTHOCT / РАЗВОJ.

\section{УВОД}

Спорт је битан чинилац свеукупног развоја личности. Кроз организовану спортску активност млади имају могућност физичког, социјалног, психолошког и васпитно-образовног развоја. Окружење и клима у спорту су ти који стварају позитивне услове за правилан развој младих спортиста. Отуда, као врло битан фактор у спорту, прије свега млађих узрасних категорија, посматра се и однос између тренера и спортиста.

Хорн (Horn, 2008) и Кревсел (Krevsel, 2001) наводе да је тренер примарни фактор у свеукупном развоју спортисте у млађим узрасним категоријама. Њихова међузависност се манифестује кроз потребу спортиста за усвајањем вјештина, компетенција и искустава тренера, односноу потреби тренераза пријеносом стечених компетенција и знања у постигнућа и успјехе спортиста (Antonini Philippe \& Seiler, 2006). Као битни чиниоци тимског и индивидуалног успјеха у спорту се наводе оданост и повјерење у овом односу (Nikbin, Hyun, Iranmanesh, \& Foroughi, 2014). Ериксон и Коте (Erickson, Cote, 2016) указују на важност одржавања добрих односа тренера и спортисте на свим нивоима. Јовет (Jowett, 2017) чак наводи да је однос између тренера и спортисте суштина цијелог тренерског посла и да тај однос дефинише ефективност тренера у своме раду. Тренер би требао континуирано развијати и усавршавати своје педагошке компетенције, како би позитивно утицао на развој и професионални успјех (Kuljić, Čokorilo, \& Grk, 2010).

Поред тога што има значајан утицај на спортски развој младих спортиста, тренер има и врло важну улогу у обликовању психосоцијалног искуства дјеце и младих у оквирима спорта (Moran \& Weiss, 2006). Рутен и сарадници (Rutten, Deković, 
Stams, Scherengel, Dirks, Hoeksma, 2008) истичу прије свега улогу коју организовани спорт има у социјализацији младихспортиста.Шериден, Кофи и Лавале (Sheriden, Coffee, Lavallee, 2014) истичу да је комбиновани ефекат тренерске, родитељске и вршњачке подршке од непроцјењивог значаја за обликовање позитивних и негативних искустава младих спортиста. Међутим, закључују да је тренер најбитнији фактор социјалне подршке у спорту млађих узрасних категорија. Резултати указују да тренери који одржавају добре односе са спортистима умањују могућност антисоцијалног понашања (Rutten, Stams, Biesta, Scherengel, Dirks, Hoeksma, 2007), као и да повећавају задовољство и срећу спортиста које тренирају (Davis \& Jowett, 2014; Jowett et al., 2017; Lafrenière, Jowett, Vallerand, \& Carbonneau, 2011; Lafrenière, Jowett, Vallerand, Donahue, \& Lorimer, 2008). Ca друге стране, битан фактор који детерминише квалитет односа тренер-спортиста су и особине личности спортисте (Aşçi, Kelecek, \& Altintaş, 2015). Свакако, битна претпоставка је да тренер својим понашањем, итекако, може утицати на мотивацију спортиста (Mageau \& Vallerand, 2003; Olympiou, Jowett, \& Duda, 2008). Резултати истраживања које је на узорку грчких студената провео Цартоф (Chartoff, 2017) указују да укључивање у разне социјалне групе, као што су спортски тимови, може бити од кључног значаја у борби против менталних болести код студената.

У фокусу литературе је био и утицај родитеља на квалитет односа тренер-спортиста (Jowett \& Timson-Katchis, 2005), као и однос родитеља и тренера у спорту млађих узрасних категорија (Preston \& Fraser-Thomas, 2016), а Јовет и Кремер (Jowett, Cramer, 2010) закључују да квалитет односа спортиста - тренер има много снажнији утицај на физичко самопоуздање од њиховог односа са родитељима. Јовет и Чонди (Jowett, Chaundy, 2004) су истраживали утицај односа тренер - спортиста на групну кохезију, док су Исоард-Готхур, Тролуд, Густафсон і Гије-Дека (Isoard-Gautheur, Trouilloud, Gautsafsson, GuilletDescas, 2016) покушали пронаћи везу између квалитета односа тренер-спортиста и прераног сагоријевања младих спортиста. Истраживан је и однос између лидерства и квалитета односа трене - спортиста (Enoksen et al., 2014; Vella, Oades, \& Crowe, 2013). Николс и Пери (Nicholls, Perry, 2016) су сагледали утицај односа тренер - спортиста на појаву и суочавање са стресом и истичу да је квалитет овог односа од посебног значаја за тренера, а мање битан за спортисту.

Дакле, тренер има посебно битну улогу у професионалном и личном развоју спортиста, прије свега јер спортисти велики дио свог времена проводе управо са тренером, понекад и много више него са родитељима. Стога, основни циљ овог истраживања је дефинисање квалитета интерперсоналног односа између тренера и спортиста утврђивањем ставова младих спортиста према раду и понашању њихових тренера. Ово истраживање је усмјерено на добијање повратне информације о позитивним и негативним аспектима овог односа и њиховим импликацијама на рад тренера, али и спортиста.

\section{МЕТОД РАДА}

Узорак испитаника је обухватио перспективне младе спортисте $(N=228)$ из Босне и Херцеговине који су учествовали на „Љетној школи спорта“ у Требињу 2017. године. Просјечна старост испитаника је била $14,69 \pm 0,95$ година, а структуру узорка су чинили спортисти из 12 спортских грана, из индивидуалних спортова 51,3\% ( $n=$ $117)$, а из екипних спортова $48,7 \%(n=111)$. Полна структура узорка је била прилично уједначена, мушки испитаници су чинили $46,9 \%(n=107)$, док су женски испитаници чинили 53,1\% ( $n=121)$ посматраног узорка.

Испитаници су попуњавали Quality Relationship Inventory (QRI), истраживачки инструмент који су развили Пирс, Сарасон, Солки-Буцел и Нејгл (Pierce, Sarason, Sarason, Solky-Butzel, Nagle, 1997). Упитник Quality Relationship Inventory je био често кориштен у испитивању различитих интерперсоналних и социјалних односа, али по први пут је употребљен у спорту, како би био објашњен квалитет односа тренер - спортиста (Jowett, 2009). Оригинални QRI, који су користили Пирс и сарадници (1997), био је сачињен од 25 ајтема, а у овом истраживању користи се скраћени упитник који је развила Јовет (Jowett, 2009) и он садржи 18 ајтема који мјере два позитивна (социјална подршка и дубина) и један негативни (конфликт) аспект односа тренер - спортиста. Свака димензија овог односа се састојала од 
шест варијабли, а испитаници су одговарали на скали од 1 (нимало) до 4 (много). Унутрашња конзистенција је била задовољавајућа за све три димензије: социјална подршка $(\alpha=0,77)$, дубина $(\alpha=0,71)$ и конфликт $(\alpha=0,80)$.

Испитаници су били упознати са циљем истраживања прије попуњавања упитника који је био на добровољној бази. Једини критеријум за попуњавање овог упитника је био да испитаник, односно спортиста, сарађује са својим тренером минимално шест мјесеци. Прикупљени подаци су потом статистички обрађени уз помоћ IBM SPSS Statistics 21.0.

Кориштена је дескриптивна статистика ка= ко би приказали просјечне вриједности и стандардне девијације за све три димензије QRI упитника, као и корелациона матрица ове три димензије. Напослијетку, анализа варијансе у мултиваријантном дизајну (MANOVA) је употребљена како би утврдили потенцијално неслагање у оцјени квалитета односа тренер спортиста.

\section{РЕЗУЛТАТИ}

Дескриптивна статистика QRI скале приказује средње вриједности и стандардне девијације у два позитивна (социјална подршка и дубина) и једном негативном (конфликт) аспекту односа тренер-спортиста (Табела 1 и 2), а примјетна је и висока корелација између сва три субтеста QRI скале (Табела 1).

Табела 1 Дескриптивна статистика и интеркорелација између три субтеста QRI скале

\begin{tabular}{lccccc}
\hline Варијабла & M & SD & Подршка & Дубина & Конфликт \\
\hline подршка & 3,12 & 0,54 & - & - \\
дубина & 3,24 & 0,47 & $0,60^{* *}$ & $-0,22^{* *}$ & - \\
конфликт & 1,77 & 0,61 & $-0,23^{* *}$ & \\
\hline
\end{tabular}

${ }^{* *} \mathrm{p}<.01$.

Табела 2 Дескриптивна статистика посматраног узорка $(\mathrm{N}=228)$

\begin{tabular}{|c|c|c|c|c|c|c|c|c|}
\hline \multirow{3}{*}{ Варијабла } & \multicolumn{4}{|c|}{ Пол } & \multicolumn{4}{|c|}{ Спорт } \\
\hline & \multicolumn{2}{|c|}{ Мушки } & \multicolumn{2}{|c|}{ Женски } & \multicolumn{2}{|c|}{ Индивидуални } & \multicolumn{2}{|c|}{ Екипни } \\
\hline & $\mathbf{M}$ & SD & $\mathbf{M}$ & SD & $\mathbf{M}$ & SD & $\mathbf{M}$ & SD \\
\hline подршка & 3,09 & 0,57 & 3,15 & 0,52 & 3,25 & 0,49 & 2,99 & 0,56 \\
\hline дубина & 3,22 & 0,50 & 3,28 & 0,44 & 3,28 & 0,49 & 3,21 & 0,45 \\
\hline конфликт & 1,85 & 0,53 & 1,72 & 0,67 & 1,85 & 0,66 & 1,71 & 0,55 \\
\hline
\end{tabular}

Занимало нас је одговарају ли мушки и женски испитаници, односно спортисти из индивидуалних и екипних спортова једнако хомогено или постоји разлика. Анализа варијансе у мултиваријантном дизајну указује да постоји статистички значајна интеракција између пола и врсте спорта на комбинацију зависних варијабли (социјална подршка, дубина и конфликт), $\mathrm{F}_{(3,222)}$
$=5,10, p<0,01$; Wilks' $\Lambda=0,93$. Даљом анализом треба установити гдје је поменута разлика.

Врста спорта којом се спортиста бави има значајан утицај на ниво социјалне подршке коју добија од свог тренера, $\mathrm{F}_{(1,228)}=20,06, p<0,01$, а пол спортисте нема значајнији утицај у истомепогледу, $\mathrm{F}_{(1,228)}=3,69, p>0,05$, док интеракција пола и врсте спорта значајно утиче на социјалну подршку у 
односу тренер - спортиста, $\mathrm{F}_{(1,228)}=14,01, p<0,01$. Примјетно је да спортисти из индивидуалних спортова имају значајније виши ниво социјалне подршке у односу на спортисте из екипних спортова, а мушки спортисти из индивидуалних спортова су изразили много виши ниво социјалне подршке од оних из екипних спортова. Такође, примјетно је и да у индивидуалним спортовима виши ниво социјалне подршке су исказали спортисти мушког пола, а у екипним спортовима женског пола (Слика 1).

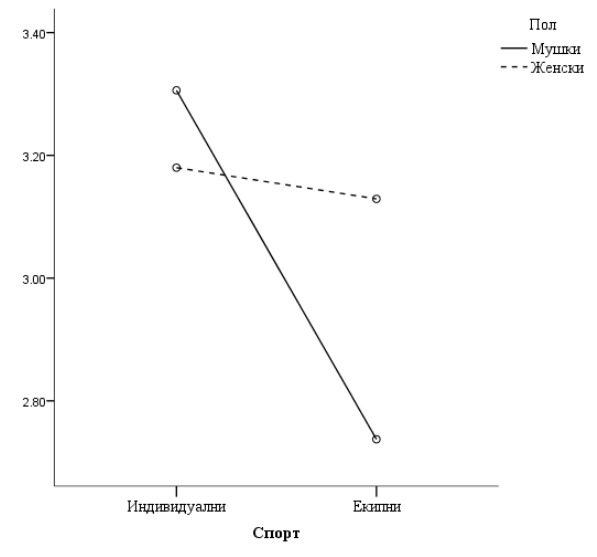

Слика 1 Утицај пола и врсте спорта на социјалну подршку у односу тренер-спортиста

Дубина односа тренер - спортиста нема статистички значајну разлику између спортиста који се баве индивидуалним, односно екипним спортовима, $\mathrm{F}_{(1,228)}=2,73, p>0,05$, нити има статистички значајну разлику у погледу пола спортисте, $\mathrm{F}_{(1,228)}=1,89, p>0,05$, док је у интеракцији пола и врсте спорта примјетна статистички значајна разлика, $\mathrm{F}_{(1,228)}=5,46, p<$ 0,05. Индивидуални спорт појачава дубину односа тренер - спортиста код мушких испитаника, док се код женских испитаника смањује и обрнуто за екипне спортове (Слика 2).

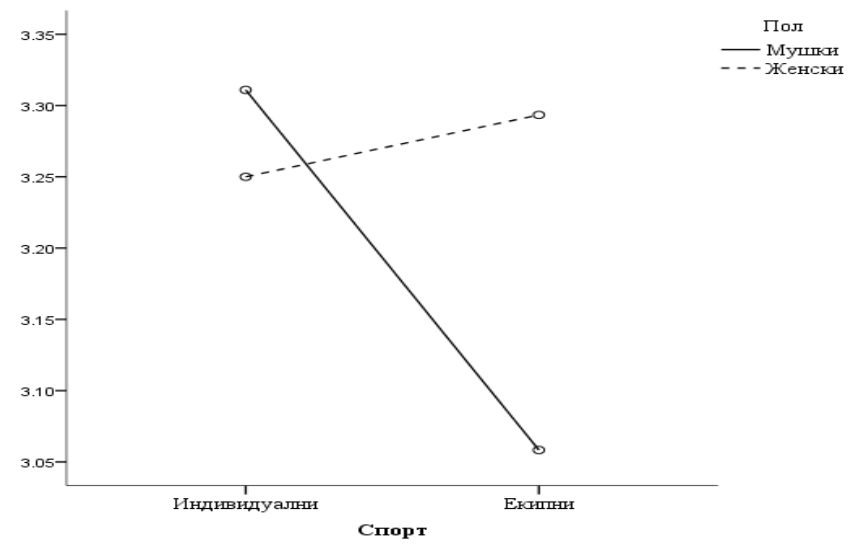

Слика 2 Утицај пола и врсте спорта на дубину у односу тренер-спортиста

Са друге стране, није пронађена статистички значајна разлика према конфликту у односу тренер - спортиста нити према врсти спорта којим се спортиста бави, $F_{(1,228)}=1,63, p>0,05$, нити према полу спортисте, $\mathrm{F}_{(1,228)}=1,98, p>$ 0,05, док је у интеракцији пола и врсте спорта пронађена статистички значајна разлика, $\mathrm{F}_{(1,228)}$ $=4,24, p<0,05$. Индивидуални спорт појачава ниво конфликта код женских спортиста, док је код мушких примјетан виши ниво конфликта у екипним спортовима (Слика 3). 


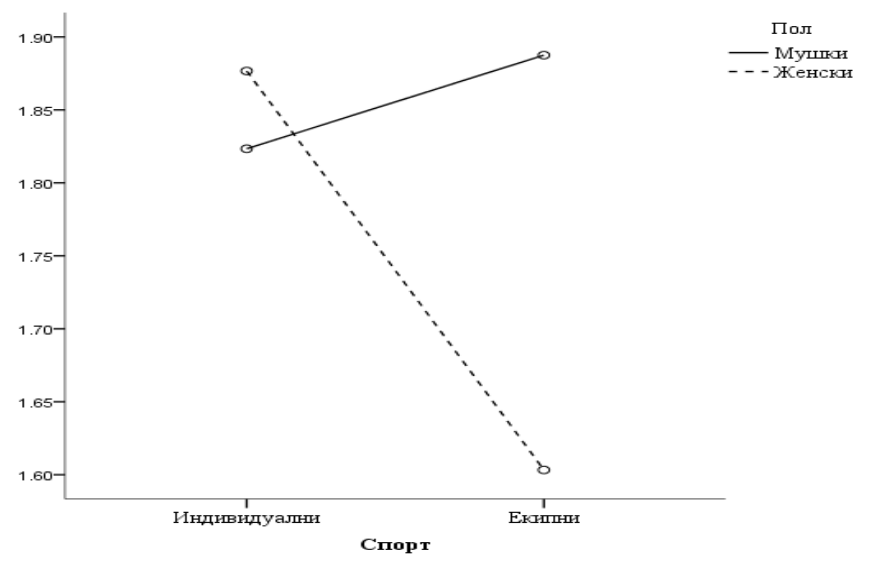

Слика 3 Утицај пола и врсте спорта на конфликт у односу тренер-спортиста

\section{ДИСКУСИЈА}

Истраживање је проведено ради дефинисања квалитета интерперсоналног односа између тренера и спортиста, утврђивањем ставова младих спортиста према раду и понашању њихових тренера. Дошло се до неколико сазнања која могу имати директан утицај на рад тренера, али и спортиста.

Три субтеста (социјална подршка, дубина и конфликт), сваки за себе, једнако хомогено пролазе код мушких и женских испитаника. Дакле, пол спортисте не игра значајну улогу у интерперсоналном односу младих спортиста из Босне и Херцеговине са њиховим тренерима. Незнатно виши ниво, у два позитивна аспекта овог односа, исказале су спортисткиње, док су мушкарци нешто склонији конфликту од жена, што је свакако и очекивана појава. Значајније разлике су примјетне између спортиста који се баве индивидуалним и екипним спортовима, док је интеракција пола спортисте и врсте спорта значајна за сва три субтеста QRI упитника. Индивидуални спортисти су исказали виши ниво у сва три аспекта односа тренер - спортиста. Ипак, са аспекта социјалне подршке у овом односу, спортисти из индивидуалних спортова су исказали значајније виши ниво у односу на њихове колеге из екипних спортова. Ово може усмјерити на закључак да су тренери у индивидуалним спортовима посвећенији и страственији у своме послу, што може бити добар показатељ квалитета односа тренера са спортистима (Lafrenière, Jowett, Vallerand, \& Carbonneau, 2011). Еноксен и сарадници (Enoksen,
Fahlshrom, Johansen, Hageskog, Christensen, 2014) наводе и да тренери из екипних спортова много више исказују аутократско понашање, у односу на колеге из индивидуалних спортова. Такође, исти аутори наводе да искуснији тренери више пажње посвећују социјалној подршци, од оних мање искусних. У овом истраживању нису посматрани аспекти односа тренер - спортиста у односу на тренерско искуство или стил вођења, али се резултати овог истраживања могу довести у везу са овим сазнањима јер је јасно да стил понашања тренера у раду има директне импликације на социјалну подршку и групну кохезију. Стил вођења тренера и однос са спортистима свакако може имати битне дугорочније импликације на мотивацију дјеце за прикључивање у одређену спортску грану, али и на могуће флуктуације младих спортиста.

Успјешно рјешавање конфликата у екипи између тренера и спортиста би свакако требало бити важно искуство за младе спортисте с обзиром да ће тиме бити мање склони вршњачкој агресији. Штавише, Јовет и Кремер (Jowett, Cramer,2010) наглашавају да присутан конфликт у овоме односу може довести до опадања физичких вјештина код младих спортиста.

Шериден, Кофи и Лавале (Sheridan, Coffee, Lavallee, 2014) истичу да је тренер најбитнији фактор социјалне подршке у спорту млађих узрасних категорија и он би, уз родитељску и вршњачку подршку, требао бити главни замајац у стварању што шире базе у некој спортској грани. Тренер заиста треба да има битну улогу у свеукупном развоју и напретку младих спортиста, a квалитетан однос са спортистима може резултирати бољим спортским постигнућима и 
постизању кључних циљева екипе (Nicholls, Earle, Earle, \& Madigan, 2017). Дакле, може се закључити да квалитет односа између тренера и спортисте утиче на више битних фактора, између осталог на антисоцијално понашање младих спортиста (Rutten et al., 2007; Rutten et al., 2008), прерано сагоријевање спортиста (Isoard-Gautheur, Trouilloud, Gustafsson, \& Guillet-Descas, 2016), ефективност тренера у своме послу (Jowett, 2017) и друге битне аспекте.

\section{ЗАКЉУЧАК}

Бављење спортом пред тренере и играче поставља високе критеријуме успјешности и из тог разлога је однос тренера и спортисте кључан у постизању врхунског спортског успјеха. Однос између тренера и спортисте је посебно битан у периоду адолесценције, када слаби однос спортисте и родитеља, а интерперсоналне релације и сазнања стечена у том периоду се код младог спортисте акумулирају за цијели живот, била она позитивна или негативна. У периоду

\section{ЛИТЕРАТУРА}

1. Antonini Phillipe, R., \& Seiler, R. (2006). Closeness, co-orentation and complementarity in coach-athlete relationship: What male swimmers say about their male coaches. Psychology of Sport and Exercise, 7(2), 159-171.

2. Aşçi, F. H., Kelecek, S., \& Altintaş, A. (2015). The Role of Personality Characteristics of Athletes in Coach-Athlete Relationships. Perceptual and Motor Skills, 121(2), 399-411.

3. Chartoff, B. (2017). Does Social Support Diminish Depression in Students? Evidence from Athletes and Greek Life. EKU Libraries Research Award for Undergraduates, 9. Retrieved from http://encompass.eku.edu/cgi/viewcontent. cgi article $=1040 \&$ context $=$ ugra .

4. Davis, L., \& Jowett, S. (2014). Coach-athlete attachment and the quality of the coach-athlete relationship: implications for athlete's well-being. Journal of Sports Sciences, 32(15), 1454-1464. адолесценције тренер врло често проводи много више времена са спортистима од њихових родитеља и тиме је његова улога у овом периоду сазријевања од кључног значаја и врло је важно колико се стручан, школован и квалитетан кадар поставља за рад са млађим узрасним категоријама.

Полазна основа у овом односу свакако мора бити комуникација, која има кључни значај за психосоцијално функционисање оба актера у овом односу, а тиме и на спортско постигнуће. Асчи и сарадници (2015) наглашавају и важност особина личности спортисте као могући врло битан предиктор квалитета односа са тренером. Из тог разлога, могући даљи правци у истраживању би могли ићи у смјеру испитивања утицаја особина личности младих спортиста на квалитет односа тренер - спортиста. Са друге стране, с обзиром да квалитет односа тренер - спортиста у великој мјери може имати утицај на спортско постигнуће код спортисте, у наредним истраживањима би требало усмјерити интересовање и на утицај квалитета односа тренера - спортиста на самопоуздање и појаву анксиозности код младих спортиста, а тиме и на њихово спортско постигнуће.

5. Enoksen, E., Fahlström, P. G., Johansen, B. T., Hageskog, C. A., Christensen, J. B., \& Høigaard, R. (2014). Perceptions of leadership behavior and the relationships to athletes among Scandinavian coaches. Scandinavian Sport Studies Forum, 5, 131-147.

6. Erickson, K., \& Côté, J. (2016). A season-long examination of the intervention tone of coachathlete interactions and athlete development in youth sport. Psychology of Sport and Exercise, 22, 264-272.

7. Horn, T. (2008). Coaching effectiveness in the sport domain. In T. Horn (Ed.) Advances in sport psychology (3rd ed., pp. 239-267). Champaign, Il: Human Kinetics.

8. Isoard-Gautheur, S., Trouilloud, D., Gustafsson, H., \& Guillet-Descas, E. (2016). Associations between the perceived quality of the coach-athlete relationship and athlete burnout: An examination 
of the mediating role of achievement goals. Psychology of Sport and Exercise, 22, 210-217.

9. Jowett, S., Adie, J. W., Bartholomew, K. J., Yang, S. X., Gustafsson, H., \& Lopez-Jiménez, A. (2017). Motivational processes in the coach-athlete relationship: A multi-cultural self-determination approach. Psychology of Sport and Exercise, 32, $143-152$.

10. Jowett, S. (2017). Coaching effectiveness: the coach-athlete relationship at its heart. Current Opinion in Psychology, 16, 154-158.

11. Jowett, S., \& Chaundy, V. (2004). An Investigation Into the Impact of CoachLeadership and CoachAthlete Relationship on Group Cohesion. Group Dynamics: Theory, Research, and Practice, 8(4), 302-311.

12. Jowett, S., \& Cramer, D. (2010). The predicition of young athletes' physical self from perceptions of relationships with parents and coaches. Psychology of Sport and Exercise, 11, 140-147.

13. Jowett, S., \& Timson-Katchis, M. (2005). Social Networks in Sport: Parental Influence on the Coach-Athlete Relationship. The Sport Psychologist, 19, 267-287.

14. Jowett, S. (2009). Validating Coach-Athlete Relationship Measures with the Nomological Network. Measurement in Physical Education and Exercise Science, 13, 34-51.

15. Krevsel, V. (2001). Poklic športnega trenerja [The profession of a coach]. Ljubljana: Univerza $\mathrm{v}$ Ljubljani, Fakulteta za šport, Inštitut za šport.

16. Kuljić, R., Čokorilo, R., \& Grk, M. (2010). Socioprofesionalni status trenera i doživljaj sopstvene pedagoške kompetencije [Socio-professional status of coaches and subjective experience of pedagogical competence]. Proceedings, 2, 65-75.

17. Lafrenière, M. A. K., Jowett, S., Vallerand, R. J., \& Carbonneau, N. (2011). Passion for coaching and the quality of the coach-athlete relationship: The mediating role of coaching behaviors. Psychology of Sport and Exercise, 12, 144-152.

18. Lafrenière, M. A. K., Jowett, S., Vallerand, R. J., Donahue, E. G., Lorimer, R. (2008). Passion in Sport: On the Quality of the Coach-Athlete Relationship. Journal of Sport and Exercise Psychology, 30, 541-560.
19. Mageau, G. A., \& Vallerand, R. J. (2003). The coach-athlete relationship: a motivational model. Journal of Sports Sciences, 21(11), 883-904.

20. Moran, M. M., \& Weiss, M. R. (2006). Peer leadership in sport: links with friendship, peer acceptance, psychological characteristics, and athletic ability. Journal of Applied Sport Psychology, 18, 97-113.

21. Nicholls, A. R., \& Perry, J. L. (2016). Perceptions of Coach-Athlete Relationship Are More Important to Coaches than Athletes in Predicting Dyadic Coping and Stress Appraisals: An ActorPartner Independence Mediation Model. Frontiers in Psychology, 7, 1-12.

22. Nicholls, A. R., Earle, K., Earle, F., \& Madigan, D. J. (2017). Perceptions of the Coach-Athlete Relationship Predict the Attainment of Mastery Achievement Goals Six Months Later: A TwoWave Longitudinal Study among F. A. Premier League Academy Soccer Players. Frontiers in Psychology, 8, 1-8.

23. Nikbin, D., Hyun, S. S., Iranmanesh, M., \& Foroughi, B. (2014). Effects of Perceived Justice for Coaches on Athletes' Trust, Commitment, and Perceived Performance: A Study of Futsal and Volleyball Players. International Journal of Sports Science \& Coaching, 9(4), 561-577.

24. Olympiou, A., Jowett, S., \& Duda, J. L. (2008). The Psychological Interface Between the Coach-Created Motivational Climate and the Coach-Athlete Relationship in Team Sports. The Sport Psychologist, 22, 423-438.

25. Pierce, G. R., Sarason, I. G., Sarason, B. R., SolkyButzel, J. A., \& Nagle, L. C. (1997). Assessing the quality of personal relationships. Journal of Social and Personal Relationships, 14, 339-356.

26. Preston, C., \& Fraser-Thomas, J. (2016). The parent-coach relationship within elite youth sport: Contentious or cooperative. Journal of Exercise, Movement, and Sport, 48(1), 125.

27. Rutten, E. A., Stams, G. J. J. M., Biesta, G. J. J., Schuengel, C., Dirks, E., \& Hoeksma, J. B. (2007). The Contribution of Organized Youth Sport to Antisocial and Prosocial Behavior in Adolescent Athletes. J Youth Adolescence, 36, 255-264.

28. Rutten, E. A., Deković, M., Stams, G. J. J. M., Schuengel, C., Hoeksma, J. B., \& Biesta, G. J. J. (2008). On-and off-field antisocial and prosocial 
behavior in adolescent soccer players: A multilevel study. Journal of Adolescence, 31(3), 371-387.

29. Sheridan, D., Coffee, P., \& Lavallee, D. (2014). A systematic review of social support in youth sport. International Review of Sport and Exercise Psychology, 7(1), 198-228.
30. Vella, S. A., Oades, L. G., \& Crowe, T. P. (2013). The relationship between coach leadership, the coach-athlete relationship, team success, and the positive developmental experiences of adolescent soccer players. Physical Education and Sport Pedagogy, 18(5), 549-561.

Примљен: 26.02.2019.

Прихваћен: 25.03.2019.

Online објављен: 26.07.2019. 